\title{
PROTOTYPE DEKSAGONAL REAKTOR
}

Dr Rahadian Zainul and Team
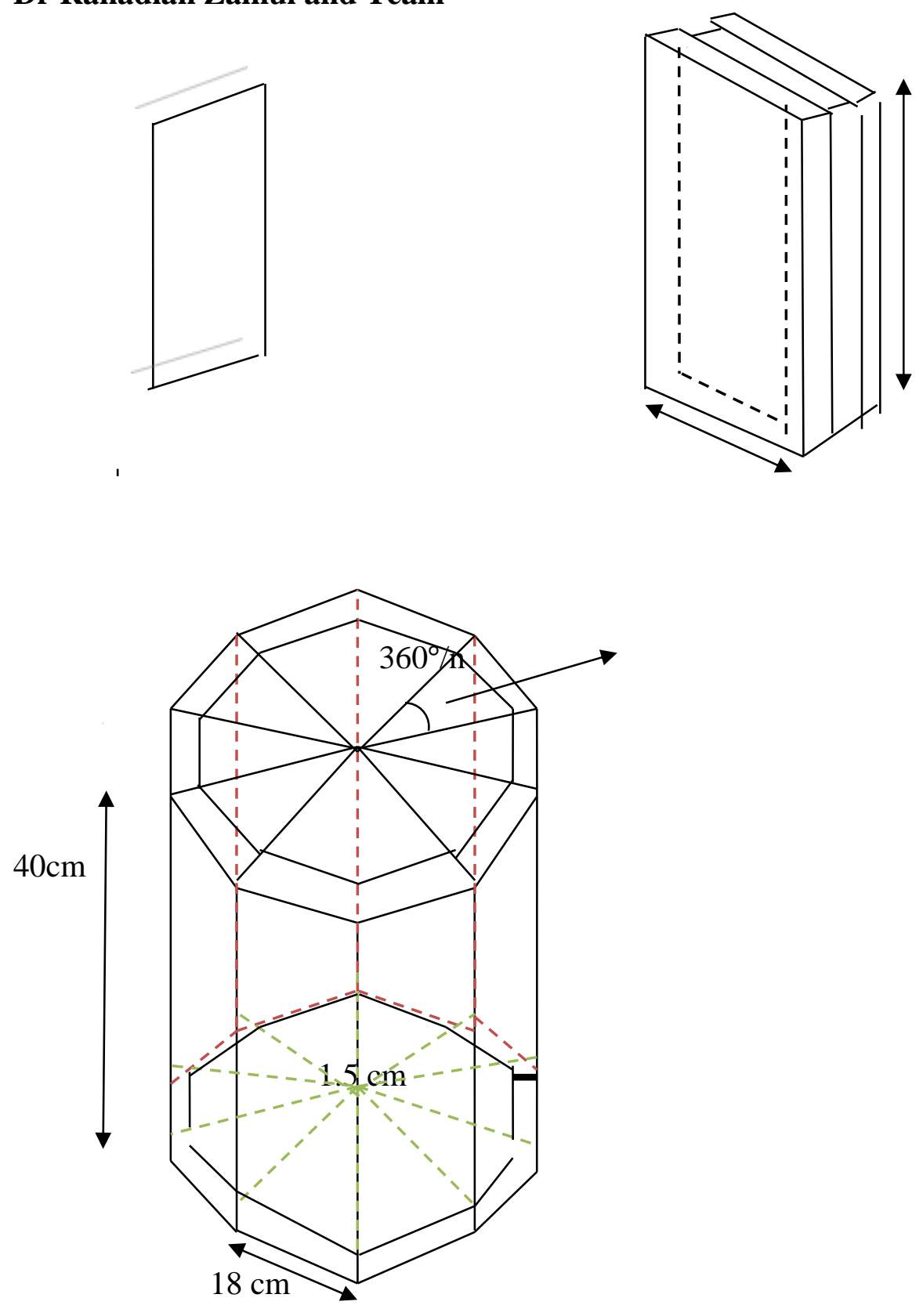

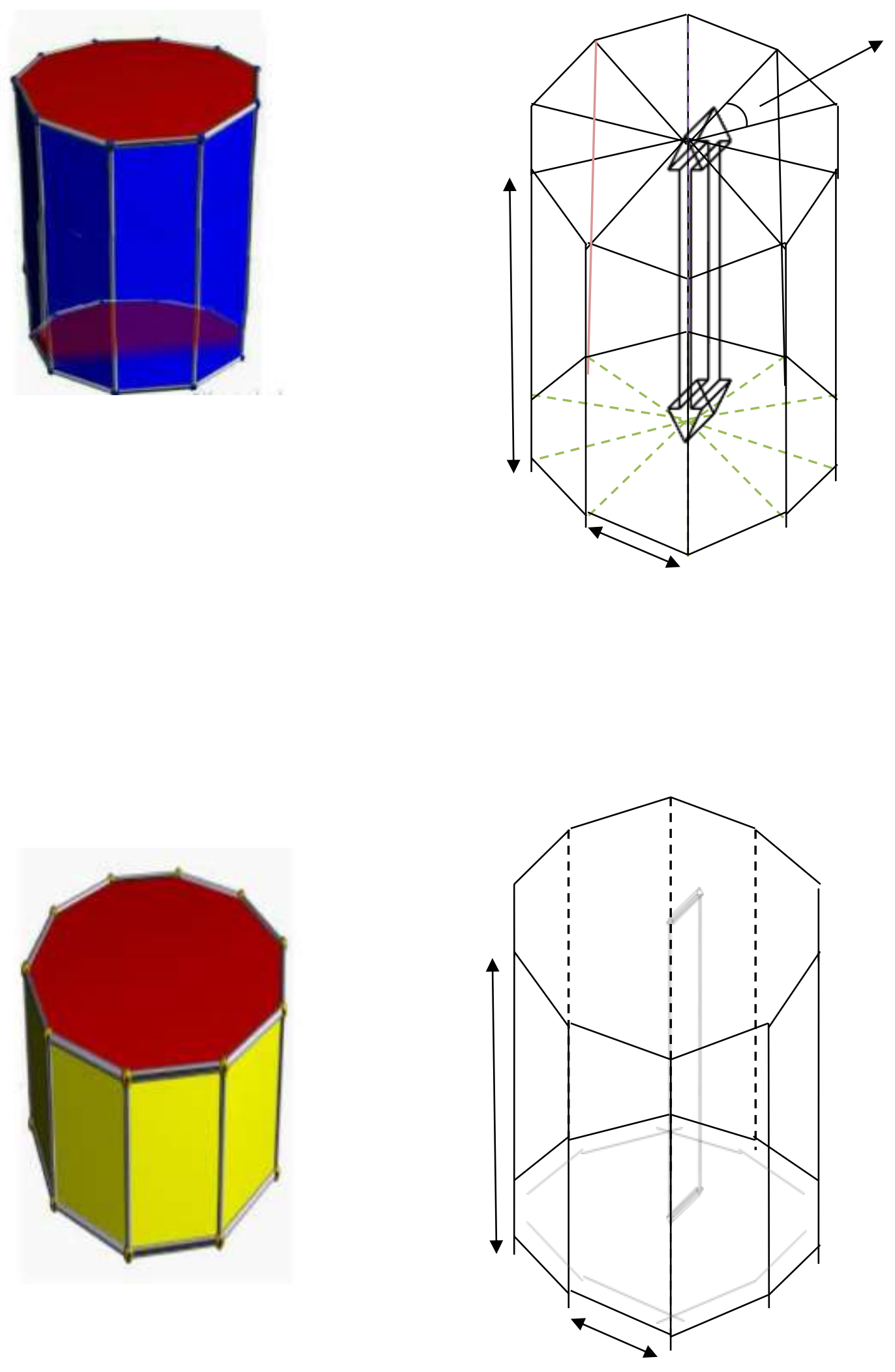